\title{
Why are myths true: Plato on the veracity of myths ${ }^{*}$
}

\section{Deretic}

University of Belgrade,

16-20, Cika Ljubina, Belgrade, 11000, Serbia

For citation: Deretic I. Why are myths true: Plato on the veracity of myths. Vestnik of Saint Petersburg University. Philosophy and Conflict Studies, 2020, vol. 36, issue 3, pp. 441-451.

https://doi.org/10.21638/spbu17.2020.302

Distinguishing myths in terms of their veracity had almost been neglected in Plato's studies. In this article, the author focuses on Plato's controversial claims about the truth-status of myths. An attempt is made to elucidate what he really had in mind when assessing the veracity of myths. The author claims that Plato, while discussing the epistemic status of myths, actually distinguished three kinds of myths in regard to what they narrate. Additionally, it is argued that he endorses three different kinds of truth value for myths: they can be either true or false, probable, or factually false but conveying some valuable truths. In the Republic II and III, Plato implicitly distinguishes the truth value of theological myths from the truth value of aetiological and normative ones, each of which are explained in detail in the article. In Plato's view, the theological myths can be either true or false, because he determines the divine nature a priori. When ascribing the probable character to myths, Plato has in mind mostly aetiological myths. Given that we are unable to establish the truths on the origins and development of many phenomena, because they originated in the remote past, what we can do is to reconstruct plausible and consistent myths of these phenomena, which, among others, might contain the arguments and even proofs, such as the proof of the cosmic destruction in Plato's own myth in the Politicus. In the third case, when Plato says that myths are lies, yet containing some truth, he had in mind myths which might be the product of our imagination like eschatological myths, for example. Being a kind of fiction, they are false, in the sense they do not correspond to any real state of affairs. Since they convey profound ethical norms or religious insights, they can be regarded as true.

Keywords: Plato, myth, veracity, truth, falsehood, the Republic.

In the Republic [1], Plato started an ongoing and never finished dialogue between philosophy and poetry ${ }^{1}$. He pointed out what he considered to be the fact that philosophy and poetry, although having something in common, conveyed different, sometimes mutually exclusive, "truths". In this paper, I will focus on Plato's controversial claims about the truth-status of myths. In doing this, I will endeavor to elucidate what Plato really had in mind when discussing the veracity of myths ${ }^{2}$. My assessment is that, while discussing the

${ }^{1}$ Poetry is a frequent theme in Plato's dialogues: The Apology, The Ion, The Republic, The Phaedrus, etc. A great number of books, essays and treatises are devoted to Plato's criticism of poetry. Among them, in my view, particularly distinguished is H. G. Gadamer's treatise: "Plato and poets", cf. [2; 3, p. 1-28; 4-8, etc.].

2 Some significant connotations of the word "myth" are analyzed in Levin's paper, cf. [8, p. 223-231].

* This research was financed by the Ministry of Science, Education and Technological Development of the Republic of Serbia within the projects no. 179064 and 179067. I am indebted to Nicholas D. Smith for his help with an earlier draft of this paper.

(c) Санкт-Петербургский государственный университет, 2020 
epistemic status of myths, Plato actually distinguished three kinds of myths in regard to what they narrate. Additionally, I will argue that he endorses three different kinds of truth value for myths: they can be either true or false, probable, or factually false but conveying some valuable truths.

Plato's discussion of the veracity of myths is introduced as a part of his educational program in the Republic (376c ff.), that is to say, at the beginning of educating and forming the character of future guardians. He highlights how it could be both significant and dangerous to immature and undeveloped individuals to be exposed to certain ideas that might corrupt their souls. Long before psychoanalysis, Plato knew that when the contents of perception enter our soul, they develop their own dynamics, which the rational aspect of our personality could find difficult to control. Thereby, "false contents" might dangerously affect primarily children's desires, emotions, and correlated beliefs because of their undeveloped cognitive and deliberative capacities.

\section{II}

In the Republic II and III (376c-392b), where the truth-status of myths is discussed extensively and in detail, Plato mostly has in mind theological and aetiological myths. In this context, theological myths refer to the narratives about gods or heroes, whose creators are both the traditional mythmakers (Homer and Hesiod) and Plato himself. His account of god frequently expressed in the form of a myth, as the rational principle and the perfect designer of the entire world (in the Thimaeus) as well as the ruler of the movement of the whole universe (in the Politicus), has already been introduced in his criticism of traditional mythology in the Republic. My claim is that Plato distinguishes the truth value of theological myths from the truth value of etiological and normative ones, which I will explain in detail.

Plato is referring to, in my view, various types of "being false" and "being true", while discussing the veracity of myths. What he says about myths in general can be sometimes applied to his own myths and indirectly to what myths should be, according to his own outlined project of a new "philosophical mythology".

In explaining what he means when claiming that traditional myths are false, Plato introduces the following comparison:

When a story gives a bad image of what the gods and heroes are like, [it is similar] ${ }^{3}$ to the

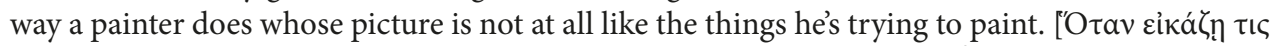

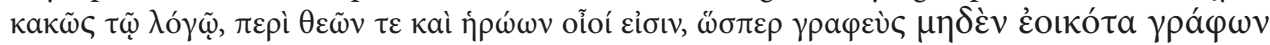

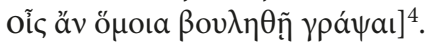

Plato compares myth-making with painting, a bad myth with a bad painting, whereby likeness is the criterion for determining how good or bad each is. With this comparison, he highlights the mimetic character of mythmaking and other artistic activities. Apparently, his intention is to explain the fallacy of myths by referring to the copy-original relation. More precisely, in Plato's view, a painting is bad if it does not look like a model or a paradigm that a painter has in mind while painting. Likewise, a myth is bad if it does not represent a pattern that it is supposed to represent. In other words, myths are true, if

3 Author's brackets.

${ }^{4}$ Cf. Resp. 377d9-e2. Unless otherwise noted, all translations provided herein are those that appear in Cooper 1997 [9]. 
they correspond to the relevant state of affairs, and they are false, if the correspondence between their narratives and that state of affairs is inapt or inadequate.

To what kind of state of affairs should theological myths correspond? Plato thinks that they should be about the nature of gods or heroes, i. e., about who they really are. Plato's argument, which supports the above-stated claim, might be presented as follows: 1) God must be represented as he really is; 2) The nature of god is good; 3) Since god is good, he cannot be the cause of something evil (or bad); 4) Mythmakers inadequately represent god as the cause of both good and evil. Consequently, myths are false if they represent god and what he causes as they are not, and myths are true if they represent god and what he causes as they really are.

More precisely, the myths are false if they describe god as the cause of something evil, because something good cannot cause something evil; on the contrary, they are true if they represent god and what he causes as something good. This argument implies Plato's very important ethical belief; that is, because god is not the cause of many things in our lives, only we are responsible for our acts, whether they are good or bad. This often opposes the description of human actions in traditional Greek myths, in which the gods determine human fate. By contrast, in Plato's view, because our conduct is not predetermined, only we are responsible for our own actions. The next "pattern" mythmakers should follow is to represent the god as a being, who doesn't change in form. Namely, both the subject of the narrative and the narrative itself must be consistent and coherent. This second "pattern" for mythmaking is more understandable when taking into account the numerous representations of gods, who frequently transform themselves not only into human beings, but also into animals. From Plato's line of thought one may draw the conclusion that his account of god is in many aspects different or even opposed to the traditional beliefs of Homer and Hesiod. According to Plato, it is highly problematic that the traditional

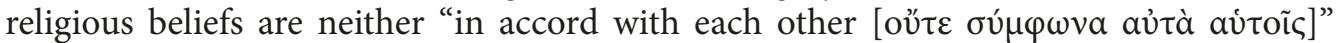
(cf. Resp. 380c3-4), nor do they represent gods in a consistent way.

Because god is perfect per definitionem, Plato holds that god is simple and consequently cannot change his own form. His argument is as follows: 1) What is perfect cannot affected by external influences; 2) What is perfect cannot change and transform itself; 3) God is perfect. Accordingly, god does not change and transform into other forms. From the very concept of being perfect and self-contained, it follows that nothing external can influence or change god. Although god does not change due to some external cause, one can pose the question whether he might change himself, which could be for the good or for the worse. Both are absurd, because something that is perfect cannot be more perfect (or better) than it is, or worse than it is. In both cases, his godlike, perfect, and selfcontained nature will be denied (cf. Resp. $381 \mathrm{~b} f f$.).

Therefore, a myth is false if it tells us about the god as changing his nature and transforming himself into various creatures, because in these cases his perfect nature would not be perfect anymore. Additionally, if the god changes his nature, then he will no longer be immortal, because only immortal beings are unchangeable. Consequently, a myth is true if it narrates in a consistent way about god as a simple, unchangeable, and perfect being. It also implies that in these myths, god or gods ought not to be represented as anthropomorphic beings who act like us, humans, frequently in vicious ways.

Plato's reflections reveal several aspects. First, he employs an extended meaning both of truthfulness and falsehood. Second, true narratives of god (or gods and heroes) are 
defined as those that correspond to his (or their) essence as it is understood by philosophers ${ }^{5}$. Third, myths should be coherent and consistent both in narrative and in subject matter. Finally and most significantly, theological myths seem to be, in Plato's view, either true or false. Indeed, they are governed by the clear patterns of what god is, that is to say, the most perfect and good being; thus, he is the cause of only good things; in addition, god is not composed, but a simple and unchangeable being. If the new myths are to be true, they have to be founded on these unambiguous and unequivocal standards ${ }^{6}$.

Having in mind these "patterns", Plato sharply criticizes Homer ${ }^{7}$, Hesiod, and the tragic poet Aeschylus and their descriptions of the gods as the creatures who brutally kill each other, showing that they are not only imperfect, but vicious and sometimes evil. For example, Hesiod tells us the story of "how Uranus behaved, how Cronus punished him

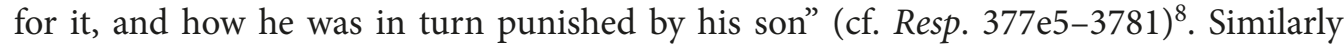
unacceptable is what Homer says of Zeus as "the distributer of both good and bad" (cf. Resp. 379c9-2e). The traditional Greek myths, which described the gods as bloodthirsty, revengeful, and evil creatures, do not represent, in Plato's view, what the gods really are, that is, in all respects good, reasonable, and perfect beings (cf. Resp. 379c ff.).

The deficiency of the traditional myth is perhaps best expressed by Plato's unusual for-

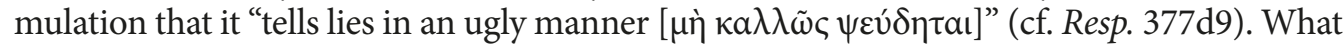
I understand him to be saying is that in the traditional Greek myths, gods and heroes are portrayed as vicious and evil beings. If they are described as having moral flaws, then the depictions of gods are logically false too. If they are portrayed in such a way, gods are not only unworthy of mimetic art, but also dangerous for causing the corruption of one's soul. We should always bear in mind that the gods as the subjects of the myths will serve as the models for emulation, because of their extraordinary nature. In other words, the first type of falsehood emerges when gods or heroes are depicted in the myths in ways that this description does not correspond to their divine nature, and when they are not consistently and coherently described. If myths satisfy these conditions, then they are indisputably true.

\section{III}

The second type of myths are aetiological ones, whose truth values are assessed differently from what I have described for theological myths. By aetiological myths, I have in mind plausible stories about the origins or genesis of something, from ancient towns like Troy to the entire universe, belonging to the distant, "timeless" past. These are introduced by Socrates' words:

It is also useful in the case of those stories we were just talking about, the ones we tell because we don't know the truth about those ancient events. By making a falsehood as much

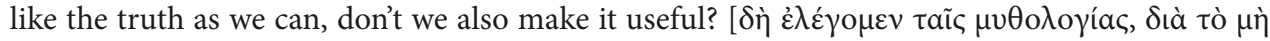

${ }^{5}$ Luc Brisson claims that a true myth does not correspond to "its supposed referent", but to a philosophical discourse which "held up a norm", cf. [10, p. 25].

${ }^{6}$ Plato's Socrates holds that poets in kallipolis must base their myths on these new "patterns", about which we have been discussing in this paper (cf. Resp.379a1 ff.).

${ }^{7}$ Margaret Battin rightly emphasizes that "Plato never claims that the gods and heroes Homer describes do not exist; he argues only that they cannot have the characteristics Homer ascribes to them, or that they are not divine", cf. [11, p. 167].

${ }^{8}$ Plato might well have had an additional objection to such stories, since they did not only imagine divinities who were immoral, but also ones who were mortal. 


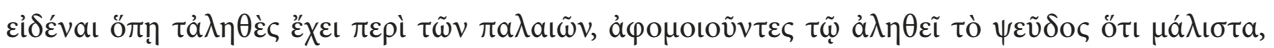

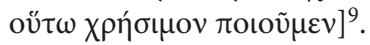

There are some problems in understanding this sentence adequately. It is suggested that stories about the very distant past are false, but our efforts can make them true. How can the stories, although false, become useful? Do not we deceive others if we deliberately narrate something that we have already known to be false, making it "as much like the truth as we can?" Why and to whom is such a deceit beneficial? One thing is certain: Plato does not have in mind the nature of god (gods), about whom, in his view, we can attain some knowledge. Thus, theological myths can be true or false, while the truth-status of aetiological myths ${ }^{10}$ is, it seems, hard to determine. Plato is right, when claiming that nobody can know much of what happened in the very distant past, about which there is a lack of evidence. As a result, there is really no way to adjudicate the veracity of these myths.

Plato's agnosticism, when the content of most aetiological myths is in question, does not imply that we should abandon all narration about things that can never be known. He rightly believes that it is highly useful to narrate myths about the distant past and the origins of various phenomena, because that it is the only way we can think about what really happened in ancient times or why things became the way they are now.

An additional problem in understanding the falsehood of myths emerges when taking into account Plato's distinction between a "falsehood in words", which is useful and even recommended in certain situations, and a "true lie [á $\lambda \eta \theta \tilde{\omega} \varsigma \psi \varepsilon \tilde{v} \delta o \varsigma]$ " (cf. Resp. $382 \mathrm{~d} 1$ ) that should always be forbidden, since it is equivalent to "ignorance in the soul" (cf. Resp. 382b7). At first glance, it appears that this distinction is more confusing and perplexing than useful in understanding the falsehood of myths. By introducing this distinction, Plato wants to explain aetiological myths in terms of "falsehood in words".

Let us, first, closely analyze this unusual kind of lie. As Margaret Battin pointed out, the "true lie" should be characterized as the "genuine lie", that is, what a lie really is [11, p. 164-165]. The second kind of falsehood is described rather figuratively as a "copy" or "imitation" of the "genuine lie". The very frequent Platonic distinction between paradigmcopy relation is herein applied to these two falsehoods. Thereby, the "true lie" is a kind of negative model, whose copy is less negative, less false than genuine falsehood, whereas in most of the Platonic model-copy relations it is the opposite, namely, the model is typically something positive, and so it is the copy that is relatively less worthy.

Plato goes on to say that a "true falsehood" deceives one's mind "about the things that are", and "about the most important things", whereas "falsehood in words" is at times beneficial as a kind of preventive "medicine (pharmakon)" against enemies and friends who "are attempting to... do something bad" (cf. Resp. 382c8-9). While the first lie "is what everyone would least of all accept"11, the second one is sometimes useful. His choice of the word "pharmakon", which means both remedy and poison, is very indicative. Plato employs this word in order to signal that all lies are potentially poisonous; only experts can use them beneficially. In other words, as Nicholas Smith illustrates, this term with

${ }^{9}$ Cf. Resp. 382d1-3. The translation I provided here modifies the Grube and Reeve translation. Their translation includes the words "involving the god", which do not exist in the Greek text, cf. [9, p. 1021].

${ }^{10}$ Most of Plato's aetological myths are interpreted in my Plato's Philosophical Mythology [12, p. 58-101].

${ }^{11}$ Cf. Resp. 382b3-4. 
both its meanings "carries with it the idea that such things are to be used only under specific circumstances, and only with appropriate expertise and good will (so see 389b2-6)" $[13$, p. 40].

Both falsehoods assert what is not that it is, i. e., they do not correspond to what really is. The difference between two types of falsehood seems to be in their intentions. Whilst the "lie in words" is deliberate, the "true lie" is a falsehood of which both the speaker and the listener are unaware. What seems to be highly problematic is that the well-intentioned lie might be a very flexible concept, which may involve significant forms of deception and hypocrisy.

Nevertheless, for Plato an important concept, employed further on in the Republic, is that of the "necessary" or "noble lie". The "Phoenician" myth ${ }^{12}$ of the metals, which is designed to promote the idea that each member of Plato's kallipolis ought to be placed in the class for which she or he is naturally suited, is an example of this sort of lie (cf. Resp. 414 b8 ff.). In short, a "lie in words", is according to Plato "necessary" and "noble"13, even though it deliberatively asserts certain factual non-veracities, when the deception is for the good of those to whom it is told. This concept is applied to the truth-status of aetiological myths that I discuss in the following passages.

When myths of ancient events taking place in the distant past are involved, it is difficult to determine how they exactly happened. There is neither empirical testimony of these events, from human or cosmic "history", nor are there rational proofs of them. Therefore, we need to supplement these reconstructions of the remote past in order to tell something about them at all. Since a myth is the only "testimony" of these events, it is important to discuss further its apparently odd truth-status.

Aetiological myths are false in the sense that, in a number of cases, the details about which they narrate are consciously made up or invented because we do not and cannot know what really happened in the remote past (which is frequently in these myths depicted as the timeless present), such as the origin of the universe or the humankind. Given the various impediments like time and distance, we do not have access to past events. Therefore, mythmakers are not fully in possession of knowledge. Although they do not convey what really happened in a very remote past, mythmakers can compose the stories about these events in a consistent and rational fashion, as if they had really happened in such a way.

By telling stories on how something originated and what followed afterwards, aetiological myths can convey a kind of truth about the nature of the phenomena involved. Although we cannot have an accurate account of what really happened at the beginning in these cases, the imagination of a mythmaker can "fill in" the gaps in our understanding of a certain phenomenon and thus make plausible sense of them.

Myth-tellers seem to create the illusion that they are telling history, and not just a story of how something might have happened. Aetiological myths are designed to resemble historical narratives in the way they tell about the sequence of events from their beginning to the present state, creating some kind of illusion that everything happened as it is described in them. Nevertheless, unlike history, which describes specific and particular

12 Роман Викторович Светлов [Roman Victorovich Svyetlov] lucidly notices the link between the various myths, in which the motive of earth born humans is elaborated, cf. [14, p.35].

${ }^{13}$ Nicholas Smith points out that the meaning of genanion as "good of its kind", which means only useful. In this case, "the word needs to not have such a lofty sense", cf. [15, p.41]. 
events, myths are meant to provide a kind of general explanation of what happened in the remote past.

Although the events represented in myths are frequently creations of the imagination, they should not be, in Plato's view, arbitrary and implausible fabrications, the purpose of which is to dazzle an uncritical or immature audience. They attempt to explain what cannot be otherwise elucidated. Such mythic "explanations" of what happened in the distant past are closer to the truth when they are consistently explained, when parts of the myths are so integrated and designed as to provide a plausible explanation of something from the distant past, about which we have no other sources.

Therefore, Plato's unusual formulation about "making a falsehood as much like the truth as we can" (cf. Resp. 382d1.) might be understood as an appeal to narrate subjects, mostly made up, in the way that they can become as plausible as possible. In order to achieve this goal, myths are intended to coincide with what had probably or most likely happened in the remote past. If myths narrate about beings, whose nature we know a priori, i. e., independently of experience, then they should not contradict the knowledge of these entities.

Plausible myths regarding the origin of certain phenomena might serve as their explanations, lacking any other testimonies, and can be, to some extent, generalized. Something similar is claimed by Plato's Athenian in the Laws [16] (cf. Leg. 682a ff.). Namely, in the explanation of how cities in general were created, Plato's Athenian refers to Homer's verses about the creation of Ilium, where it is told that Ilium was founded when the population descended "from the hills to a wide and beautiful plain" and "near several rivers which poured down from Ida above” (cf. Leg. 681e2-5.). Aetiological myths might be regarded as an inference to a best explanation. Mythmakers attempt to offer the best explanans for some present and observable explanandum.

In characterizing this kind of myth, Plato's Athenian in the Laws claims that it was

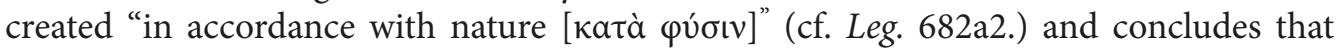
when poets are inspired by god, they express the truth. Moreover, these myths, including the one about the creation of Ilium, attempt to provide explanations of what is in the present and observable, such that there is resemblance and continuity in the ways the present is explained in terms of the mythical past. Homer's explanation of how Ilium was founded might serve as an example of how other larger settlements were formed. This supports my claim that Plato believes that some myths can be plausible, if they adequately and reasonably describe the nature of a particular phenomenon that can be generalized in some cases.

Certain myths are not to be characterized as fabrications, but as the only way of explaining the phenomena in question - which Plato considers to be the "true" one because it fits the nature of things. And this kind of plausible explanation should be employed for rational accounts of things that cannot be explained otherwise. The mythic evidence can be credible and sound; even some of them were confirmed by later discoveries (i. e., archeological ones). Even without access to such confirmation, Plato was able to recognize the epistemic validity of this kind of poetry, even when some of its elements were subjected to his serious criticism.

Plato's expression "Eikò $\varsigma$ ú $\theta$ oc" seems to signify most adequately the truth-status of myths, particularly aetiological ones. Namely, these myths are likely and credible tales about something, i. e., they are well thought out, plausible, and convincing stories. In the Timaeus [17], Plato characterizes his own myth (cf. Tim. 29d.) on "the gods and the 


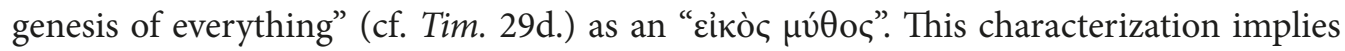
that his cosmology is nothing more than a plausible story. Myles Burnyeat [18] provides a

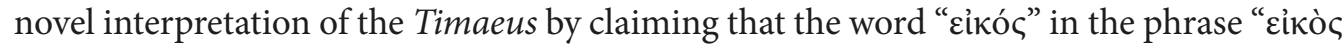
$\mu v ́ \theta$ oc" means not only "probable", as it is commonly rendered, but also "reasonable, appropriate, and fitting" [18, p. 171].

In the Timaeus, Plato frequently replaces the word "mythos" with the word "logos", in order to emphasize that his cosmological myth is reasonable, sound, and appropriate. Nevertheless, he does not accidently call his cosmology a myth, since it is also a theogony, i.e., a story of the divine nature of the cosmos. Furthermore, it is a likely story, which resembles the truth as much as possible. Like many other human creations, this myth is limited and imperfect, and provides only an image, a more or less exact copy of what really was in the beginning. Moreover, cosmology is the merely "likely story", because it tells us about the visible universe and its origin and genesis, which is in itself, as Plato says, only an "image" of the intelligible, per se existing Forms. In other words, for Plato cosmology is related to the Theory of Forms, as the becoming is related to the eternal being (the Forms) ${ }^{14}$. About the origin of the entire universe, we have neither empirical testimonies nor proofs. Thus, according to Plato, we are composing a kind of narrative, whose purpose is to reasonably, consistently, and appropriately explain how the visible universe originated. In composing such stories not only reason plays an important role but also imagination is involved.

\section{IV}

What Plato says in the beginning of the discussion about the truth value of myths seems to be unexpected. He attributes not only falsehood to myths, but also truthfulness as follows: "These [myths] ${ }^{15}$ are false, on the whole, although they are telling some truth [Toũto $\delta \dot{\varepsilon} \pi$ glance, it is not clear how something can be both true and false. A preliminary answer to this question might be that myths are true in one sense, and false in another. This implies that we should determine in what sense they are false, and in what sense they are true.

This is the third kind of myth, in my view, in terms of their veracity. I will call them normative myths because it is on the basis of the quality of the norms that Plato regards these tales as true. The normative myths are the factually false narratives which convey some normative ideals that Plato considers to be true. For example, they include not only Plato's eschatological or ethical myths, but also some traditional ones. The eschatological myths ${ }^{17}$, frequent in Plato's dialogues, narrate about the life of the soul after death, about the judgment of the soul, its environment, and choices, etc.

The content of these myths is consciously made up, which seems to be the most obvious in Socrates' myth in the Phaedo [19]. Specifically, Plato's Socrates indicates that this myth is not even credible by saying that "no sensible man would insist that these things are

${ }^{14}$ In an epistemic sense, the "plausible" myth is only a kind of belief [ $\pi$ í $\left.\sigma \tau \iota c\right]$, which corresponds to the

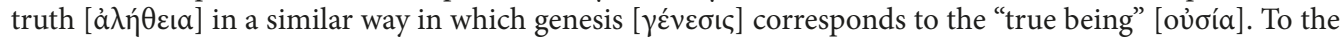

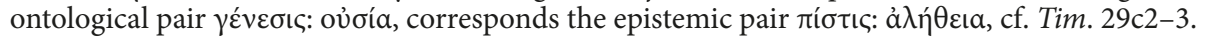

${ }^{15}$ Inserted by the author.

16 Author's translation.

${ }^{17}$ I interpret Plato's most significant eschatological myths in my book Plato's Philosophical Mythology [Платонова филозофска митологија], cf. [12, p. 147-232]. 
as I have described them" (cf. Phd. 114d1-2). The importance of that myth lies neither in stating certain necessary truths on god's nature and the phenomena that he causes, nor in telling some plausible truths, but in conveying certain cosmological, ethical and religious beliefs. On the other hand, Plato presents most of the traditional myths as being false because they convey wrong ethical beliefs (cf. Resp. 377e ff.).

Now we are approaching the very important meaning of being a true myth. Both Plato and we share the same opinion that most of myths are made up, and in that sense false ${ }^{18}$. Although designed as an intentional non-veracity, a myth can promote certain insights upon the nature of our soul, its dynamic structure, as well as normative truths, etc. These stories cease to be merely a kind of fiction, i. e., fabricated tales, since they might convey to us the truths of who we are and what we should be. In other words, they also express ethical ideals, that is to say, guidelines of our conduct, religious beliefs and other insights of philosophical significance. On the one hand, these myths are false in a sense that they are made up, but, on the other, they are true because they express general normative ideals. Therefore, Plato seems to be right when claiming that some myths lie, yet they contain truth.

Our assessment that theological, aetiological, and normative myths can be classified in terms of their veracity faces a problem. There are myths that are designed to be aetiological, yet whose truth value seems to be assessed in terms of their normative value. The already mentioned Phoenician myth of the metals is presented as an example of an aetiological myth, explaining how the different kinds of people-golden, silver and bronze-had already been formed beneath the earth before they came into existence (cf. Resp. 414d ff.). This myth is seemingly aetiological by providing the pseudo explanation of why each member of the ideal polis, in Plato's view, should be placed in the class for which he or she is naturally suited. This myth pretends to be an aetiological one whose veracity is verisimilitude, but, in fact, it is obviously false as the product of the imagination ${ }^{19}$. Because of it, the Phoenician myth only appears to be an aetiological one, but it is actually a "noble lie", It is a fiction whose aim is to promote what is the most beneficial for all members of kallipolis according to its wise rulers, that is to say, its philosopher kings and queens.

I have argued that theological myths, or the theological parts of a myth, can be either true or false since the divine nature is determined a priori. Given that we are unable to establish the truths on the origins and development of many phenomena because they originated in the remote past, what we can do is to reconstruct plausible and consistent myths of these phenomena, which, among others, might contain the arguments and even proofs, such as the proof of the cosmic destruction in Plato's own myth in the Politicus. When ascribing the probable (Eikòৎ) character to myths, Plato has in mind mostly aetiological myths, both his own and those of others. These myths might, to some extent, even contribute to science. In the third case, when Plato says that myths are lies, yet containing some truth, he meant myths which might be the product of our imagination, for example eschatological myths. Being a kind of fiction, they are false in the sense they do not correspond to any real state of affairs. But since they convey profound ethical norms or

${ }^{18}$ Christopher Gill rightly claims that although myths, whether Plato's or the ones, he criticizes, are fictional, that is not the purpose of Plato's discussion of falsity in connection with poetry and mythmaking. Additionally, Gill argues that there is no "clear distinction between factual and fictional discourse in Plato", cf. $[20$, p. $41,51-52]$.

${ }^{19}$ I owe this point to Nicholas Smith. 
religious insights, they can be regarded as true. Moreover, such myths inspire us to think beyond the already established framework. They might make us face the frequently unsolvable, philosophical, moral and religious questions, and dilemmas that Plato so vividly portrayed in his own myths.

\section{References}

1. Plato (1997), Republic, in Cooper, J.M. (ed.), Plato, Complete works, Indianapolis: Ind, Hackett Pub, pp. 971-1223.

2. Gadamer, H. G. (1984), Platon und Dichter, in Gadamer, H. G., Gesammelte Werke, ed. by Mohr, J. C. B., vol. 5, Tübingen: Mohr Siebeck, pp. 249-262.

3. Annas, J. (1982), Plato on the Triviality of Literature, in Moravcsik, J. M.E. and Temko, P. (eds), Plato on Beauty, Wisdom, and the Arts, Totowa, N. J.: Rowman and Littlefield.

4. Ferrari, G. R. F. (1990), Plato and Poetry, in Kennedy, G. A. (ed.), The Cambridge History of Literary Criticism, vol. 1, Cambridge: Cambridge University Press, pp. 92-148.

5. Asmis, E. (1992), Plato on poetic creativity, in Kraut, R. (ed.), The Cambridge Companion to Plato, Cambridge: Cambridge University Press, pp. 338-364. Press.

6. Gould, T. (1990), Ancient quarrel between philosophy and poetry, Princeton: Princeton University

7. Levin, H. (1959), Some Meanings of Myth, Daedalus, vol. 88, no. 2, pp. 223-231.

8. Moss, J. (1992), What is imitative poetry and why is it bad?, in Ferrari, G.R.F. (ed.), The Cambridge Companion to Plato's Republic, Cambridge: Cambridge University Press, pp. 415-444. Pub.

9. Cooper, J. M. and Hutchinson, D. S. (eds) (1997), Plato, Complete works, Indianapolis: Ind, Hackett

10. Brisson, L. (2004), How Philosophers Saved Myths: Allegorical Interpretation and Classical Mythology, Chicago: University Of Chicago Press.

11. Battin, M.P. (1977), Plato on True and False Poetry, The Journal of Aesthetics and Art Criticism, vol. 36, no. 2, pp. 163-174.

12. Deretic, I. (2014), Platonova filozofska mitologija, Belgrade: Zavod za udžbenike.

13. Platon (1990), Werke in 8 Bänden (griechisch-deutsch), Darmstadt: Wissenschaftliche Buchgesellschaft.

14. Svetlov, R. V. (2014), Myth from the dialogue "statesman" and the first "battle for history", Vestnik Russkoi Khristianskoi Gumanitarnoi Akademii, vol. 15, no. 4, pp. 33-39. (In Russian)

15. Smith, N. D. (2019), Summoning Knowledge in Plato's Republic, Oxford: Oxford University Press.

16. Plato (1997), Laws, in Cooper, J.M. (ed.), Plato, Complete works, Indianapolis: Ind, Hackett Pub, pp. 1318-1616.

17. Plato (1997), Timaeus, in Cooper, J.M. (ed.), Plato, Complete works, Indianapolis: Ind, Hackett Pub, pp. 1224-1291.

18. Burnyeat, M. F. (2009), Eikos Muthos, in Partenie, C. (ed.), Plato's Myths, Cambridge: Cambridge University Press, pp. 167-186.

19. Plato (1997), Phaedo, in Cooper, J.M. (ed.), Plato, Complete works, Indianapolis: Ind, Hackett Pub, pp. 49-100.

20. Gill, C. (1993), Plato on Falsehood - not Fiction, in Gill, C. and Wiseman, T. P. (eds), Lies and Fiction in the Ancient World, Liverpool: Liverpool University Press, pp. 38-87.

Received: October 14, 2019

Accepted: July 2, 2020

Author's information:

Irina Deretic — PhD in Philosophy, Professor; ideretic1@gmail.com 


\section{Почему мифы истинны: Платон о достоверности мифов ${ }^{\star}$}

\section{И. Деретич}

Белградский университет,

Республика Сербия, 11000, Белград, ул. Чика Любина, 16-20

Для цитирования: Deretic I. Why are myths true: Plato on the veracity of myths // Вестник СанктПетербургского университета. Философия и конфликтология. 2020. Т. 36. Вып. 3. С. 441-451. https://doi.org/10.21638/spbu17.2020.302

Современное платоноведение нередко упускает из виду эпистемологический аспект проблемы изучения мифа. Автор указывает на противоречивый характер утверждений Платона о достоверности мифов, уделяя особое внимание анализу рассуждений философа о критериях их оценки с позиций истинности/ложности. В первой и второй книгах «Государства» содержится имплицитное деление мифов на три группы теологические, этиологические и нормативные, причем этиологические включены в нормативные. Такое деление связано с их эпистемологическими характеристиками, различными для каждой группы мифов: для теологических приемлема только одна из возможных характеристик такого рода - истина или ложь; этиологические характеризуются по принципу правдоподобия, как вероятностные; нормативные мифы как истинные в одном смысле и ложные в другом. Теологические мифы определяют божественную природу, поэтому они могут быть как истинными, так и ложными (но никогда - истинными и ложными одновременно). При описании мифов, имеющих вероятностный характер, Платон подразумевает этиологические мифы: если невозможно установить истину о происхождении и развитии тех или иных феноменов (например, из-за древности их происхождения), остается возможность реконструировать их генезис, создать достоверные мифы. Далее, утверждая, что мифы - это ложь, хотя они и содержат некоторые истины, Платон, по-видимому, имеет в виду мифы как продукт воображения (например, эсхатологические). Такие мифы ложны, поскольку имеют своим источником выдумку и не соответствуют реальности. Одновременно их можно считать истинными, поскольку эти мифы содержат истинное понимание мира и человека, передавая глубокие этические нормы или религиозные идеи. Отмечается, что этот тип мифов послужил материалом для развития различных направлений греческой поэзии. Итак, в статье предлагается следующая эпистемологическая классификация платоновских мифов: ложные и истинные; вероятные; вымышленные (фактически ложные, но передающие определенные глубокие истины и ценности).

Ключевые слова: Платон, миф, достоверность, истина, ложь, «Государство».

Статья поступила в редакцию 14 октября 2019 г.; рекомендована в печать 2 июля 2020 г.

Контактная информация:

Деретич Ирина — канд. филос. наук, проф.; ideretic1@gmail.com

* Исследование подготовлено при финансовой поддержке Министерства науки, образования и технологического развития Республики Сербия в рамках проектов № 179064 и 179067. 